J. Clin. Chem. Clin. Biochem.

Vol. 19, 1981, pp. 1021-1026

\title{
Stability of Macro Creatine Kinases and Creatine Kinase Isoenzymes Compared: Heat Inactivation Test for Determination of Thermostable Creatine Kinases
}

\author{
By J. Bohner, W. Stein, W. Renn, R. Steinhart and M. Eggstein \\ Abteilung für Innere Medizin IV (Dir. Prof. Dr. M. Eggstein), Medizinische Universitätsklinik Tübingen
}

(Received March 11/June 1, 1981)

Summary: Creatine kinase isoenzymes showed decreasing thermal stability and increasing lability towards $\mathrm{pH}$ changes in the order: $\mathrm{MM}, \mathrm{MB}$, and $\mathrm{BB}$. The three isoenzymes exhibited their highest stability between $\mathrm{pH} 6.5$ and 7.0 . At $37^{\circ} \mathrm{C}$ and an almost physiological $\mathrm{pH}$ of 7.5 the decay constants were $0.025,0.164$, and $0.580 \mathrm{~h}^{-1}$ (MM, MB, and $\mathrm{BB}$ isoenzyme), respectively.

In contrast to free creatine kinase $\mathrm{BB}$, immunoglobulin-linked creatine kinase $\mathrm{BB}$ (macro creatine kinase $\mathrm{BB}$, type 1 macro creatine kinase) showed a markedly higher stability; this accounts for the persistence of creatine kinase BB activity in macro creatine kinasaemia. In addition we identified a second type of macro creatine kinase in patients' sera, which is also thermostable.

A simple heat inactivation test $\left(20\right.$ minutes, $45^{\circ} \mathrm{C}$, immunoinhibition of the M-subunits) differentiates thermostable macro creatine kinases from thermolabile creatine kinases and thus completes isoenzyme diagnosis.

\section{Stabilität von Makro-Kreatinkinasen und Kreatinkinase-Isoenzymen: Hitzeinaktivierungs-Test zum Nachweis thermostabiler Kreatinkinasen}

Zusammenfassung: In der Reihenfolge Kreatinkinase MM, MB und BB nimmt die Thermostabilität der Isoenzyme ab und ihre Labilität gegenüber pH-Veränderungen zu. Die höchste Stabilität weisen alle drei Isoenzyme zwischen pH 6.5 und 7.0 auf. Bei $37^{\circ} \mathrm{C}$ und einem annähernd physiologischen $\mathrm{pH}$ von 7.5 bestimmten wir die folgenden Inaktivierungs-Konstanten: $0.025 \mathrm{~h}^{-1}(\mathrm{MM}), 0.164 \mathrm{~h}^{-1}$ (MB) und $0.580 \mathrm{~h}^{-1}$ (BB).

Im Gegensatz zur freien Kreatinkinase BB ist die immunglobulingebundene Kreatinkinase BB (Makro-Kreatinkinase BB, Makro-Kreatinkinase Typ 1) erheblich stabiler. Dies erklärt das Persistieren der BB-Aktivität im Plasma von Patienten mit Makro-Kreatinkinasämie.

Zusätzlich konnten wir eine zweite, ebenfalls thermostabile Form von Makro-Kreatinkinasen in Patientenseren identifizieren. Durch einen einfachen Hitze-Inaktivierungs-Test $\left(20 \mathrm{~min}, 45^{\circ} \mathrm{C}\right.$, Immuninhibition der M-Monomere) lassen sich die thermostabilen Makro-Kreatinkinasen von den thermolabilen Isoenzymen der Kreatinkinase abgrenzen. Dieser Test liefert zusätzliche Informationen bei der Isoenzymdiagnostik der Kreatinkinase.

\section{Introduction}

In a study on the stability of serum creatine kinase ${ }^{1}$ ) Morin (1) postulated that creatine kinase isoenzymes $\mathrm{MM}, \mathrm{MB}$ and $\mathrm{BB}$ undergo two distinct types of inactivation: a reversible inactivation based on an oxidative process and an irreversible one which is caused presumably by thermal inactivation. Moreover, several investigations indicated that $B B$ is the most unstable of

1) Nonstandard abbreviations used: Creatine kinase: CK, ATP: creatine-phosphotransferase, EC 2.7.3.2; CK-MM, CK-MB, CK-BB: Striated muscle type, heart type, brain type creatine kinase isoenzymes. all creatine kinase isoenzymes, when exposed to freezethawing, light and/or heating (1-3).

One form of macromolecular creatine kinase demonstrated in patients' sera was identified as a complex between creatine kinase BB and immunoglobulins (4-8). In contrast to uncoupled creatine kinase $\mathrm{BB}$, the immunoglobulin-linked BB was described as strikingly thermostable $(4,7)$.

It is the intention of this study to compare the thermal stability of creatine kinase isoenzymes with that of macro creatine kinases (two forms), and to define the conditions of a heat stability test for recognition of macro creatine kinases in the routine laboratory. 


\section{Materials and Methods}

Sera studied

Serum samples were assayed on the same day or kept frozen at $-20^{\circ} \mathrm{C}$ without any additive until used. 23 sera with macro creatine kinase were detected by the immunoinhibition test (Merckotest ${ }^{\circledR}$ CK-MB, No. 14326, Merck, Darmstadt, FRG), showing a characteristically high ratio of " $\mathrm{CK}-\mathrm{MB}$ " to total creatine kinase. These sera were investigated further by exclusion chromatography on Sephadex G-200 (8) or Sephacryl S-300 sf $(210 \times 9 \mathrm{~mm})$ to confirm the macromolecular form of creatine kinase. In every case we identified macro creatine kinase by electrophoresis in agarose gel, by ion exchange chromatography and by immunological methods with specific antisera against creatine kinase isoenzymes and immunoglobulins as described elsewhere $(5,8)$. Furthermore we characterized two different forms of macro creatine kinases (types 1 and 2 ) by their binding properties towards radiolabeled creatine kinase isoenzymes (radioelectrophoresis) and protein A-Sepharose CL-4B, and by their Michaelis constants and activation energies' $(9,10)$.

\section{Isoenzyme purification}

Human uterus, heart, and skeletal muscle obtained from autopsy or surgery were used as tissue sources of creatine kinase $B B, M B$ and $\mathrm{MM}$, respectively. All tissues were homogenized in Tris buffer $(50 \mathrm{mmol} / \mathrm{l}, \mathrm{pH} 7.0)$ at $20^{\circ} \mathrm{C}$ without an SH-protecting agent. The extracts were clarified by centrifugation $(30000 \mathrm{~g}, 20 \mathrm{~min}$, $4{ }^{\circ} \mathrm{C}$ ), and the resulting supernates were applied to a $210 \mathrm{X}$ $9 \mathrm{~mm}$ column of DEAE-Sepharose CL-6B (Pharmacia Fine Chemicals, Uppsala, Siveden) equilibrated with starting buffer (1 mmol/l Tris, pH 8.5). The selective elution of creatine kinase isoenzymes was performed by a linear buffer gradient ranging from 1 to $50 \mathrm{mmol} / 1$ Tris ( $\mathrm{pH} 7.0$ ) and 0 to $500 \mathrm{mmol} / \mathrm{l} \mathrm{NaCl}$. The enzyme-containing fractions were pooled, ultrafiltrated with $50 \mathrm{mmol} / \mathrm{l}$ Tris buffer ( $\mathrm{pH} \mathrm{7.0)}$, than concentrated with an Amicon concentrator (membrane UM 10, Amicon, Witten, FRG) and stored at $4{ }^{\circ} \mathrm{C}$. The purity of creatine kinase isoenzyme preparations was verified by electrophoresis on agarose gel (No. 745, Sigma Chemie, München, FRG) and by immunoprecipitation with antibodies against $\mathrm{M}$ - and $\mathrm{B}$-subunits (Nos. 11642 and 11643, Merck, Darmstadt, FRG).

\section{Enzyme assays}

Creatine kinase activity was measured at $25^{\circ} \mathrm{C}$ with the $\mathrm{N}$-acetylcysteine reactivated method (Boehringer Mannheim, FRG) according to the recommendations of the German Society of Clinical Chemistry (11) with an analyzer ACP 5040 (Eppendorf Gerätebau, Hamburg, FRG). We used inhibiting antibodies against the M-monomer (immunoinhibition test $=$ Merckotest $^{\circledR}$ CK-MB) to differentiate the activity of creatine kinase MM from that of macro creatine kinases in the patients' sera.

\section{Thermal stability studies}

Purified human creatine kinase isoenzymes were diluted with cleared (by filtration), heat-inactivated $\left(1 \mathrm{~h}\right.$ at $\left.60^{\circ} \mathrm{C}\right)$, pooled serum to obtain creatine kinase activities ranging from 350 to $550 \mathrm{U} / 1\left(25^{\circ} \mathrm{C}, \mathrm{N}\right.$-acetyl-cysteine-activated method). Such isoenzyme-supplemented sera were stored at $4{ }^{\circ} \mathrm{C}(\mathrm{pH} 7.0)$ overnight, and tested by isoenzyme electrophoresis before use. Patients' or isoenzyme-enriched sera were divided into six 3-ml portions in polystyrene tubes with caps $(55 \times 12 \mathrm{~mm}$, No. 112101 , Greiner, Nürtingen, FRG), and the $\mathrm{pH}$ was adjusted at $37^{\circ} \mathrm{C}$ (AVL Gas Check Type 937, AVL, Schaffhausen, Switzerland) to $6.0,6.5,7.0,7.5,8.0$, and 8.5 with minimal volumes of $\mathrm{HCl}$ or $\mathrm{NaOH}$. All sera were allowed to remain at room temperature for $1 \mathrm{~h}$ before incubation at $37^{\circ} \mathrm{C}$. Aliquots were taken periodically, and rapidly cooled in an ice bath before creatine kinase analysis was performed. The $\mathrm{pH}$ value of each sample was measured before and after the experiment.

Decay constants $\left(K_{d}\right)$ were calculated from the slope of creatine kinase activities in a semi-logarithmic plot by means of linear regression. Half lives are then given by $t_{1 / 2}=\ln 2 / K_{d}$.

\section{Heat inactivation test}

Creatine kinase isoenzymes dissolved in native sera of healthy volunteers (total creatine kinase activity $<40 \mathrm{U} / 1$, activity after immunoinhibition $<2 \mathrm{U} / \mathrm{l}$ ) to give activities from 200 to $500 \mathrm{U} / 1$, served as references, $\mathrm{pH}$-values of macro-creatine kinase-containing sera and isoenzyme-supplemented sera were measured before heating the samples for 20,40 , and 60 minutes at $45^{\circ} \mathrm{C}$. Creatine kinase activities were assayed before and after heat inactivation; the immunoinhibition test was also used in order to avoid interference in the determination of macro creatine kinase by creatine kinase MM.

\section{Results}

\section{Stability studies}

Figures 1.1-1.3 illustrate the thermal stability of creatine kinase isoenzymes at $37^{\circ} \mathrm{C}$ stored in serum matrix (heatinactivated human serum) without antioxidant. Exposed to $37^{\circ} \mathrm{C}$ creatine kinase $\mathrm{BB}$ showed a very pronounced loss of catalytic activity compared with the creatine kinase MB; this loss is even greater when compared with the MM isoenzyme. At an almost physiological $\mathrm{pH}$ of 7.5 the decay constants of $\mathrm{BB}, \mathrm{MB}$, and $\mathrm{MM}$ activities were $0.580,0.164,0.025 \mathrm{~h}^{-1}$ (half lives: 1.2, 4.2, 28.3 hours), respectively. The three isoenzymes exhibited their highest stability between $\mathrm{pH} 6.5$ and $\mathrm{pH}$ 7.0. Whereas enzyme activities decreased abruptly at lower $\mathrm{pH}$ values, the decrease was more continuous at basic pHs. Table 1 summarizes the results of our calculations of decay constants. The regression coefficients for the half life curves ranged from 0.90 to 0.99 .

In comparison, the sera of two patients containing predominantly immunoglobulin G-linked creatine kinase BB (macro creatine kinase BB, type 1 macro creatine kinase) showed a markedly higher thermal stability than noncomplexed BB, and in one case (Rud.M.) even exceeded the stability of creatine kinase MM (fig. 2.1 and tab. 2).

In addition, these complexed creatine kinases $\mathrm{BB}$ proved to be considerably more stable at lower and higher $\mathrm{pH}$ values than the creatine kinase isoenzymes. Evidently, complex formation between creatine kinase $\mathrm{BB}$ and immunoglobulins leads to protection of enzyme against thermal degradation and improved its stability towards $\mathrm{pH}$ shifts.

One of the macro creatine kinase $\mathrm{BB}$ enzyme activities (Fro.M.) had an optimal stability at pH-values from 6.5 to 7.0 like isoenzymes $\mathrm{MM}, \mathrm{MB}$, and $\mathrm{BB}$, but the other case (Rud.M.) showed its lowest $K_{d}$ value at the distinctly higher $\mathrm{pH}$ of 7.4 (tab. 2).

\section{Heat inactivation test}

Twenty three different sera from 15 patients with confirmed macro creatine kinasaemia (12 of type 1, 3 of type 2) and, for reference purposes, sera supplemented with creatine kinase $\mathrm{BB}, \mathrm{MB}$ or $\mathrm{MM}$, were heated at $45^{\circ} \mathrm{C}$. Total activity of macro creatine kinase sera ranged from 26 to $251 \mathrm{U} / 1$ (mean $88 \mathrm{U} / \mathrm{l}$ ), and 68, per cent of creatine kinase activity on average was not inhibited by 


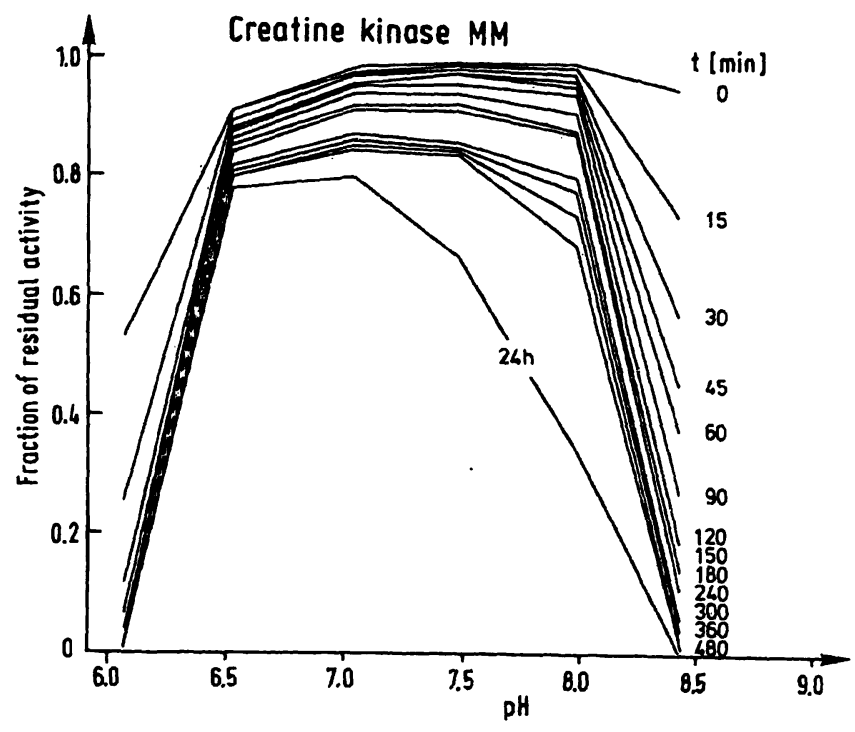

1.1

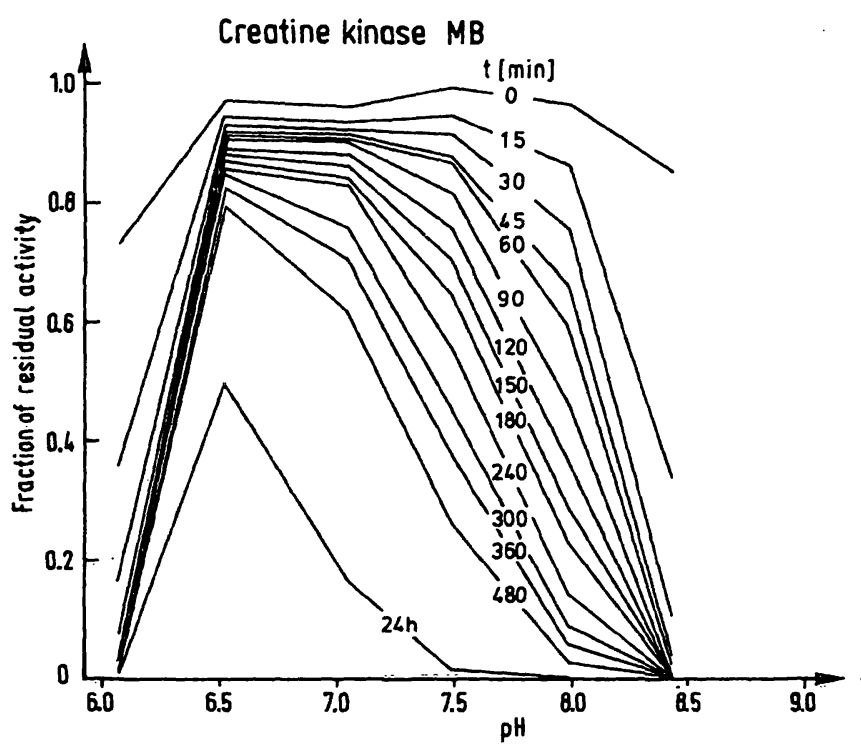

1.2

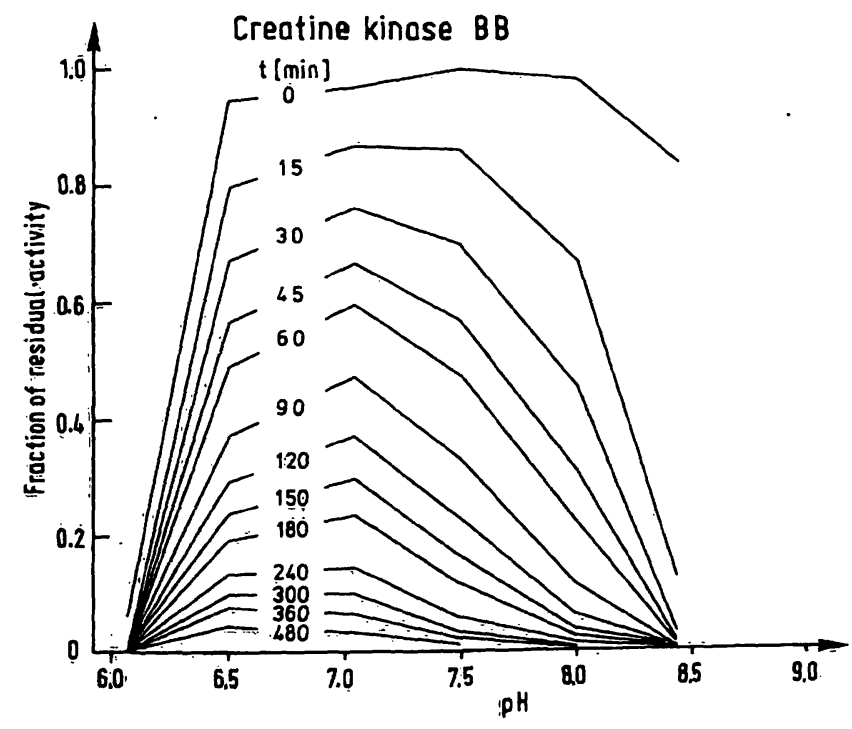

1.3
Tab. 1. Effect of $\mathrm{pH}$ on the decay constants of creatine kinase isoenzymes in serum matrix at $37^{\circ} \mathrm{C}$. The decay rates of isoenzymes based on 13 measurements (in duplicates) of creatine kinase activities over a period of 8 hours without the $24 \mathrm{~h}$ values. The pHs of samples were measured immediately before and after experiment.

\begin{tabular}{|c|c|c|c|}
\hline \multirow[t]{2}{*}{$\mathrm{pH}$} & \multicolumn{3}{|c|}{$K_{d}$ values $\left(h^{-1}\right)$} \\
\hline & $\begin{array}{l}\text { Creatine } \\
\text { kinase MM }\end{array}$ & $\begin{array}{l}\text { Creatine } \\
\text { kinase MB }\end{array}$ & $\begin{array}{l}\text { Creatine } \\
\text { kinase } B B\end{array}$ \\
\hline $\begin{array}{l}6.07 \\
6.52 \\
7.04 \\
7.49 \\
7.99 \\
8.43\end{array}$ & $\begin{array}{l}2.071 \\
0.015 \\
0.021 \\
0.025 \\
0.049 \\
0.509\end{array}$ & $\begin{array}{l}3.112 \\
0.022 \\
0.051 \\
0.164 \\
0.457 \\
2.909\end{array}$ & $\begin{array}{r}13.816 \\
0.382 \\
0.429 \\
0.580 \\
1.120 \\
4.306\end{array}$ \\
\hline
\end{tabular}

anti-creatine kinase- $M$ antibodies. Evidently, freezing and thawing of the macro creatine kinase sera increased the $\mathrm{pH}$ value when compared with that of the creatine kinase isoenzyme references $(7.9 \pm 0.5$ versus $7.7 \pm 0.4$, means and 2 S-limits).

The results of this inactivation procedure are summarized in table 3. As expected creatine kinase BB (MB) rapidly lost its activity, showing 12 (32), 8 (18), and 7 (12) percent of the initial creatine kinase activities after 20 , 40 and 60 minutes, respectively.

In contrast to the other isoenzymes MM indicated a considerably higher stability comparable with macro creatine kinases. To differentiate heat-stable macro.creatine kinase from creatine kinase $M M$ we determined the enzyme activities of the patients' sera and of the $\mathrm{BB}$ and $\mathrm{MB}$ references after inhibition with anti-creatine kinase-M. In this way interference by creatine kinase MM was excluded completely during the heat inactivation test (fig. 3): After heating 22 different sera containing macro creatine kinases (17 of type 1,5 of type 2) for 20 minutes at $45^{\circ} \mathrm{C}$, activities, determined by the immunoinhibition test, decreased to $88 \pm 25$ percent $(\bar{x} \pm 2 s)$ of the initial activity, whereas creatine kinase BB (MB) activities were reduced to residual values of $5 \pm 4(27 \pm 11)$ percent $(\bar{x} \pm 2 s, 16$ determinations in seven days).

\section{Discussion}

As reported by Nealon et al. (12) the storage stability of human creatine kinase is profoundly affected by $\mathrm{pH}$. Thiol agents or chelators known to preserve creatine

Fig. 1.1-1.3. Thermal stability diagrams of creatine kinase isoenzymes in serum matrix at $37^{\circ} \mathrm{C}$. Initial enzyme activities ranged from 350 to $550 \mathrm{U} / \mathrm{l}$. All values based on duplicates. No preservatives were added. Before use the serum-enzyme mixtures were stored overnight $\left(4^{\circ} \mathrm{C}\right)$ at neutral $\mathrm{pH}$; after adjusting the $\mathrm{pH}$ the samples were allowed to equilibrate for $1 \mathrm{~h}$ $\left(22^{\circ} \mathrm{C}\right)$. Y-axis: Ratio of residual to initial activity. 


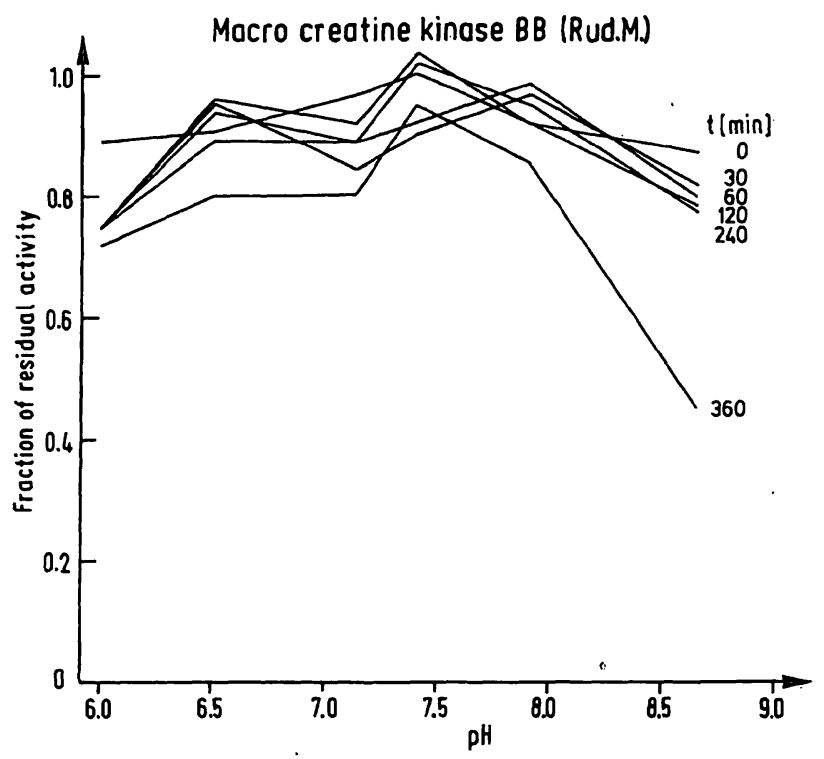

2.1

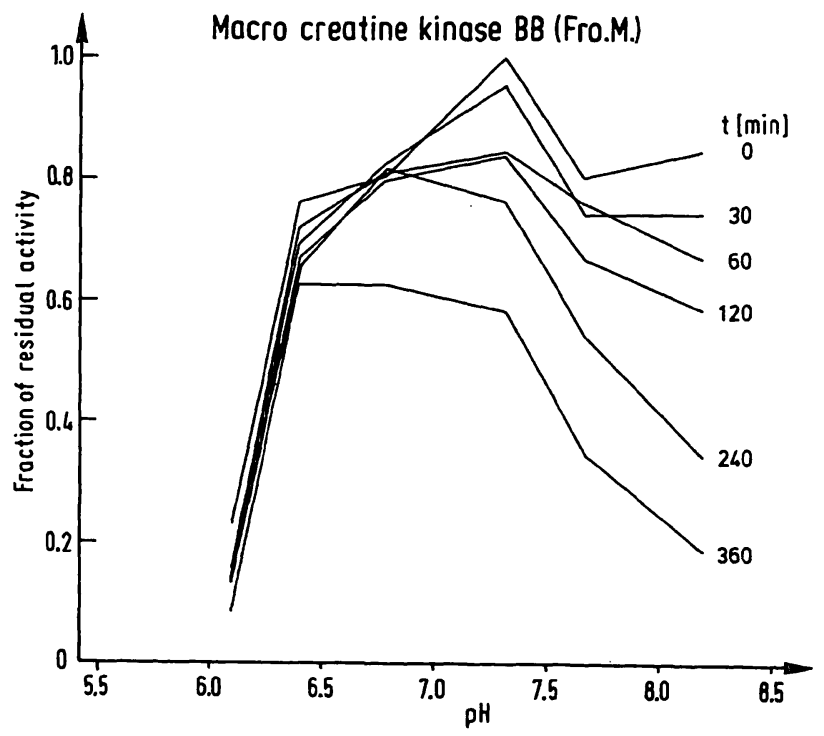

2.2

Fig. 2.1-2.2. Thermal stability diagrams of two macro creatine kinases type 1 (sera Rud.M. and Fro.M.) at $37^{\circ} \mathrm{C}$. $\mathrm{Y}$-axis: Ratio of residual to initial activity.

Tab. 2. Effect of $\mathrm{pH}$ on the decay constants of two macro creatine kinases type 1 (sera Rud.M. and Fro.M.) at $37^{\circ} \mathrm{C}$. The stability test was performed as described for creatine kinase isoenzymes.

+: Activities increased slightly during the experiment causing a negative result for the decay constant.

\begin{tabular}{llll}
\hline $\mathrm{pH}$ & $\begin{array}{l}\mathrm{K}_{\mathrm{d}} \text { values. }\left(\mathrm{h}^{-1}\right) \\
\text { Macro creatine } \\
\text { kinase BB } \\
\text { (Rud.M.) }\end{array}$ & $\mathrm{pH}$ & $\begin{array}{l}\mathrm{K}_{\mathrm{d} \text { values }\left(\mathrm{h}^{-1}\right)} \\
\text { Macro creatine } \\
\text { kinase BB } \\
\text { (Fro.M.) }\end{array}$ \\
\hline 6.00 & 0.020 & 6.10 & 0.120 \\
6.51 & 0.024 & 6.40 & 0.028 \\
7.14 & 0.019 & 6.79 & 0.033 \\
7.41 & + & 7.32 & 0.081 \\
7.92 & 0.015 & 7.67 & 0.134 \\
8.67 & 0.092 & 8.19 & 0.245 \\
\hline
\end{tabular}

Tab. 3. Heat inactivation of creatine kinase isoenzymes added to native human serum, and of macro creatine kinases $(23$ different sera of 15 patients, 12 of type 1,3 of type 2 ). The $\mathrm{pH}$ of each sample was determined before test. Activities were measured as duplicates before and after heating for 20,40 and 60 minutes at $45^{\circ} \mathrm{C}$. The results are expressed as ratio of residual to initial activity $(\bar{x} \pm 2 s)$.

Time of Residual creatine kinase activity after heat inactivation

\begin{tabular}{|c|c|c|c|c|}
\hline $\begin{array}{l}\text { heating } \\
\text { (min) }\end{array}$ & MM & MB & BB & Macro \\
\hline & $\begin{array}{l}(\mathrm{pH}= \\
7.7 \pm 0.4)\end{array}$ & $\begin{array}{l}(\mathrm{pH}= \\
7.7 \pm 0.4)\end{array}$ & $\begin{array}{l}(\hat{\mathrm{p} H}= \\
7.7 \pm 0.4)\end{array}$ & $\begin{array}{l}(\mathrm{pH}= \\
7.9 \pm 0.5)\end{array}$ \\
\hline 0 & 1.00 & 1.00 & 1.00 & 1.00 \\
\hline 20 & $\begin{array}{l}0.75 \pm 0.29 \\
(n=12)\end{array}$ & $\begin{array}{l}0.32 \pm 0.11 \\
(n=14)\end{array}$ & $\begin{array}{l}0.12 \pm .0 .09 \\
(n=14)\end{array}$ & $\begin{array}{l}0.80 \pm 0.27 \\
(n=23)\end{array}$ \\
\hline 40 & $\begin{array}{l}0.56 \pm 0.23 \\
(n=11)\end{array}$ & $\begin{array}{l}0.18 \pm 0.04 \\
(n=13)\end{array}$ & $\begin{array}{l}0.08 \pm 0.05 \\
(n=13)\end{array}$ & $\begin{array}{l}0.69 \pm 0.34 \\
(n=23)\end{array}$ \\
\hline 60 & $\begin{array}{l}0.40 \pm 0.21 \\
(n=11)\end{array}$ & $\begin{array}{l}0.12 \pm 0.04 \\
(n=13)\end{array}$ & $\begin{array}{l}0.07 \pm 0.04 \\
(n=13)\end{array}$ & $\begin{array}{l}0.62 \pm 0.40 \\
(n=23)\end{array}$ \\
\hline
\end{tabular}

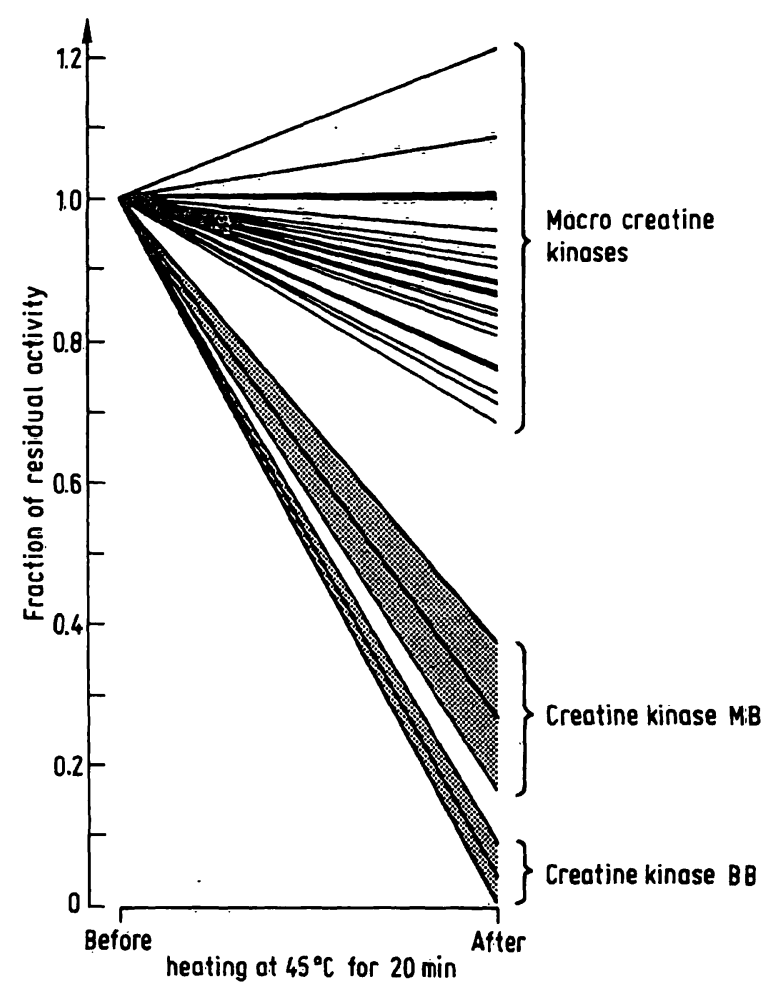

Fig. 3. Heat inactivation of macro creatine kinase sera $(n=22$, 17 of type 1,5 of type 2) and creatine kinase isoenzymes $\mathrm{BB}$ and $\mathrm{MB}$ by incubation for 20 minutes at $45^{\circ} \mathrm{C}$. Before and after heating, the creatine kinase activities of the sera were determined after inhibition of the M-subunits. by antibodies. The hatched areas represent means and $\pm 2 \mathrm{~s}$ ranges of residual creatine kinase $\mathrm{BB}$ and creatine kinase MB activities. 
kinase activity give little or no protection above $\mathrm{pH} 7.5$, and at $\mathrm{pH} 8.5$ they also contribute to enzyme instability. Correspondingly in our in vitro experiments we found an optimal stability for creatine kinase isoenzymes between $\mathrm{pH} 6.5$ and 7.0 at the physiological temperature of $37^{\circ} \mathrm{C}$, with a dramatic loss of activities at lower and higher $\mathrm{pH}$ values. The process of enzyme inactivation was considerably more pronounced for creatine kinases $\mathrm{BB}$ and $\mathrm{MB}$ than for creatine kinase $\mathrm{MM}$.

Szász et al. (13) described a rapid loss of the MM activity in serum matrix without thiol protection and recovered about 75,50 , and 10 percent of initial activities after 3 , 6 , and $24 \mathrm{~h}$ of storage at $37^{\circ} \mathrm{C}$. In this study the activities of creatine kinases $\mathrm{MB}$ and $\mathrm{BB}$ decreased to about 20 and 10 percent after $3 \mathrm{~h}$, and to 10 and 5 percent after $6 \mathrm{~h}$ of exposure to $37^{\circ} \mathrm{C}$. These half lives of creatine kinase isoenzymes are consistent with our results determined at basic $\mathrm{pH}$ values higher than $\mathrm{pH}$ 8.0. Morin (1) studied activity decay rates of creatine kinase isoenzymes under experimental conditions similar to those presented here $\left(37^{\circ} \mathrm{C}\right.$, heat-inactivated serum as matrix) but he also failed to define serum $\mathrm{pH}$ values. Therefore his decay constants calculated for creatine kinase isoenzymes $M M, M B$, and $B B\left(0.050,0.130\right.$ and $\left.0.370 \mathrm{~h}^{-1}\right)$ are hardly comparable with our results. $\mathrm{K}_{\mathrm{d}}-\mathrm{MB}$ of Morin (1) is approximately consistent with our value, when estimated at $\mathrm{pH} 7.5\left(0.164 \mathrm{~h}^{-1}\right)$. However, we determined a remarkably lower $K_{d}$ for isoenzyme $M M(0.025)$, and a higher one for $\mathrm{BB}\left(0.580 \mathrm{~h}^{-1}\right)$. These discrepancies in $K_{d}$ values could be caused by a different preparation or preexperimental storage of creatine kinase isoenzymes, because a varying content of inactivated creatine kinase molecules reactivated during the stability experiments leads to falsely low $\mathrm{K}_{\mathrm{d}}$ values. This, however, does not explain the relatively higher $\mathrm{K}_{\mathrm{d}}-\mathrm{BB}$ determined in the present work.

In this connection King et al. (14) studied the effect of exercise on total serum creatine kinase activity in vivo and found a clearly higher stability for creatine kinase $\mathrm{MM}\left(\mathrm{K}_{\mathrm{d}}\right.$ from 0.013 to $\left.0.017 \mathrm{~h}^{-1}\right)$; this corresponds more closely with our results at optimal $\mathrm{pH}$-values from 6.5 to 7.0 than with the latter investigations (Steele et al. (15): $0.0516 \mathrm{~h}^{-1} ;$ Norris et al. (16): $0.0426 \mathrm{~h}^{-1}$ ) performed in vițro,

The high sensitivity of creatine kinase isoenzymes to $\mathrm{pH}$ may be an important aspect in the enzymatic estimation of the extent of myocardial infarct $(17,18)$. The release of total creatine kinase and creatine kinase MB required for the determination of infarct size depends directly on $K_{d}$. Nevertheless $K_{d}$ values of the cardiac specific isoenzyme MB measured by Horder et al. (19) were scattered over a wide range from 0.050 to $0.139 \mathrm{~h}^{-1}$ in 14 individual cases, and Chapelle et al. (20) found no significant correlation between the survival rate of patients and the infarct size estimated by half life curves of creatine kinase MB. The authors ascribed these findings to a heterogenous distribution of the enzyme in myocardium.
In our opinion changes of blood $\mathrm{pH}$ occurring during myocardial infarction must be included in the assessment of the infarct size by enzymatic methods. Depending on the extent of acidosis, $K_{d}$ values of isoenzyme MB may be decreased by a factor two to three (table 1), leading to erronous results for the extent of myocardial necrosis Macro creatine kinase type 1 was proved to be immunoglobulin G-linked (4-7) and a typical antigen-antibody complex $(21,22)$. During a further study concerning the occurrence of macromolecular creatine kinase we detected a second type, which differed in some physicochemical properties (electrophoretic mobility, elution pattern on ion exchange chromatography, substrate affinity towards creatine phosphate, activation energy) from type 1 macro creatine kinase, and likewise is not inhibited by anti-creatine kinase-M antibodies $(9,10)$. We confirmed the thermal stability of macro creatine kinase type 1 compared with that of creatine kinase $B B$ reported by others $(4,7)$. Additionally we determined the $K_{d}$ values and found that thermal stability is a common characteristic of both types of macro creatine kinase. Furthermore, we ascertained that macro creatine kinase is more stable when subjected to $\mathrm{pH}$ shifts. These observations could explain the persistence of serum creatine kinase activity in patients with macro creatine kinasaemia $(4,5,6,7)$. Obviously macro creatine kinases are also protected from in vivo degradation.

Free creatine kinase $\mathrm{BB}$ and macro creatine kinase in patients' sera are the two well documented causes for a false positive "CK-MB" test by the immunoinhibition procedure $(4,5,6,7,8,23,24,25)$; therefore it may be of diagnostic interest to separate both of the enzyme forms. By the heating procedure macro creatine kinases decreased to a minimum of 63 percent of the initial activity, whereas the isoenzymes $\mathrm{BB}$ (MB) showed a residual activity of $9(38)$ percent at the most. We therefore propose a limit of 55 percent to discriminate macro creatine kinases from thermoinstabile creatine kinase isoenzymes (figure 3 ).

Clearly, the diagnosis of macro creatine kinase by heat inactivation is limited by reduced sensitivity of the creatine kinase assay at low serum enzyme activity. However, we proved macro creatine kinase in one case with a low total creatine kinase of $26 \mathrm{U} / 1$ (19 U/1 after immunoinhibition). Furthermore the test may be disturbed if creatine kinase $\mathrm{BB}$ (or $\mathrm{MB}$ ) and macromolecular creatine kinase both exist in a patient's serum - a probably rare event.

\section{Conclusion}

For a diagnostic tool the heat inactivation test is simple to perform in the routine laboratory, it completes creatine kinase isoenzyme diagnosis by differentiating thermostable macro creatine kinases and contributes to the recognition of falsely positive "CK-MB" tests (ion exchange chromatography, immunoinhibition) or unusual isoenzyme patterns in electrophoresis. 


\section{References}

1. Morin, L. G. (1977) Clin. Chem. 23, 646-652.

2. Perry, B., Doumas, B. \& Jendrzejczak, B. (1979) Clin. Chem. $25,625-628$.

3. Morin, L. G. (1976) Clin. Chem. 22, 92-97.

4. Ürdal, P. \& Landaas, S. (1979) Clin. Chem. 25, 461-465.

5. Bohner, J., Stein, W., Kuhlmann, E. \& Eggstein, M. (1979) Clin. Chim. Acta 97, 83-88.

6. Chemnitz, G., Jockers-Wretou, E., Schmidt, E., Schmidt, F. W. \& Lobers, J. (1979) J. Clin. Chem. Clin. Biochem. 17, 725-729.

7. Jockers-Wretou, E. \& Plessing, E. (1979) J. Clin. Chem. Clin. Biochem. 17, 731-737.

8. Stein, W., Bohner, J., Eggstein, M. \& Lang, H. (1979) J. Clin. Chem. Clin. Biochem. 17, 739-745.

9. Stein, W., Bohner, J. \& Steinhart, R. (1981) J. Clin. Chem. Clin. Biochem. 19, 239.

10. Bohner, J., Stein, W., Steinhart, R., Würzburg, U. \& Eggstein, M., in preparation.

11. Empfehlungen der Deutschen Gesellschaft für Klinische Chemie (1977) J. Clin. Chem. Clin. Biochem. 15, 249-254.

12. Nealon, D. A., Pettit, S. M. \& Henderson, A. R. (1980) Clin. Chem. 26, 1165-1169.

13. Szász, G., Gerhardt, W. \& Gruber, W. (1978) Clin. Chem. 24, $1557-1563$.

14. King, S. W., Statland, B. E. \& Savory, J. (1976) Clin. Chem. 22,1203
15. Steele, B. W., Yasmineh, W. G., Cohn, J. N. \& Winkel, P. (1976) Clin. Chem. 22, 1202.

16. Norris, R. M., Whitlock, R. M. L., Barrat-Boyes, C. \& Small, C. W. (1975) Circulation 51, 614-620.

17. Sobel, B. E., Bresnahan, G. F., Shell, W. E. \& Yoder, R. D. (1972) Circulation 46, 640-648.

18. Shell, W. E., Lavelle, J. F., Covell, J. W. \& Sobel, B. E. (1973) J. Clin. Invest. 52, 2579-2590.

19. Hфrder, M., Nièlsen, B. L. \& Petersen, P. H. (1978) In: Proceedings Symposium: Determination of creatine kinase MB activity in the diagnosis of acute myocardial infarction. Stockholm, p. 63-81.

20. Chapelle, J.-P., Albert, A., Heusghem, C., Smeets, J.-P. \& Kulbertus, H. E. (1980) Clin. Chim. Acta 106, 29-38.

21. Bohner, J. \& Stein, W. (1980) Bull. Schweiz. Ges. Klin. Chem. $21,42-47$.

22. Stein, W., Bohner, J., Krais, J. \& Müller, M. (1980) J. Clin. Chem. Clin. Biochem. 18, 677 .

23. Lang, H., Würzburg, U., Neumeier, D., Knedel, M., Prellwitz, W., Kattermann, R., Schlehbusch, H. \& Schürmann, J. (1978) Klin. Wochenschr. 56, 641-646.

24. Doran, G. R. (1979) Clin. Chim. Acta 92, 415-419.

25. Flenker, I., Sabin, G., Neuhausen, P. \& Ricken, D. (1979) Lab. Med. 3, 214-218.

Dr. Jürgen Bohner Dr. Dr. Wolfgang Stein Medizinische Universitätsklinik Abteilung für Innere Medizin IV Otfried-Müller-Str. 10

D-7400 Tựbịngen 